\title{
Analysis of Output Growth, Inflation and Interest Rates on Stock Market Return in Nigeria
}

\author{
Kola Olorunleke, Ph.D \\ Business Administration Department, Adekunle Ajasin University \\ Akungba-Akoko, Ondo State, Nigeria \\ E-mail: kolaleke52@gmail.com
}

Received: August 19, 2014 Accepted: September 4, 2014

doi:10.5296/ber.v4i2.6436 URL: http://dx.doi.org/10.5296/ber.v4i2.6436

\begin{abstract}
This paper investigates the impact of output growth, interest rate and inflation rate on stock market returns both in the short run and long run using time series data for Nigeria for the period from 1986 to 2012. Using ordinary least squares (OLS), cointegration test and granger causality, the study findings suggest that NSE-All share index, inflation rate, interest rate and real GDP move together in the long run. Also, we found that interest rate and output growth have significant role on stock market return and performance. This suggests that interest rate represents alternative investment opportunities. Finally, we infer from the causality test that NSE-All Share Index has a feed-back effect on the rate of inflation and real gross domestic product and found a support for fisher effect for Nigeria.
\end{abstract}

\section{Introduction}

Stock markets play an important role in the financial sector development of any economy, especially in developing economies. An efficient capital market can promote economic growth by providing long term investment opportunities that will attract both domestic and foreign capital. Following an increasing amount of empirical evidence obtained by many researchers, we might conclude that a range of financial and macroeconomic variables predict stock market returns and performance. For instance, Muradoglu et al. (2000) asserted that the relative size of the respective stock market and their integration with world markets might be the source of link between stock returns and macroeconomic variables. In the study of Wongbampo and Sharma (2002) using five macroeconomic variables for Malaysia, Indonesia, Philippines, Singapore and Thailand showed that in the long run all the five stock price indexes were positively related to growth in output and inversely related to the aggregate price level. For Philippines, Singapore and Thailand their result established a negative relationship between stock prices and interest rate while it revealed that positive relationship exist for Indonesia and Malaysia. 


\section{$\triangle$ Macrothink}

Business and Economic Research

ISSN 2162-4860

2014, Vol. 4, No. 2

Similar Wongbampo and Sharma (2002), the studies of Maysami and Koh (2000) and Kolari (2001) also provided support for negative relationships between stock returns with changes in price levels

Some attempts have been made to study the effects of output growth, interest rate and inflation rate on stock performance in Nigeria. For example, Udegbunam and Eriki (2001) found that the stock prices are motivated by the level of economic activities measured by GDP, interest rate, money stock, and financial deregulation. Also, Asaolu \& Ogunmuyiwa (2011) investigates whether dynamics in macroeconomic variables explain movements in share prices in Nigeria applying Granger Causality test, Co-integration and Error Correction Method (ECM) on time series data from 1986-2007. Their results revealed that a weak relationship exists between stock prices and the selected macroeconomic variables. Victor and Kuwornu (2011) in their study employed the ordinary least square estimation model in the context of the Box-Jenkins time series methodology in establishing the relationship between macroeconomic variables and stock market returns in Ghana. Using monthly data that spans from January 1992 to December, 2008 , the study reports that there is a significant relationship between stock market returns and consumer price index (inflation). Omotor (n.a) in his paper on the relationship between Inflation and Stock Market Returns that stock market returns may provide an effective hedge against inflation in Nigeria. The result showed a significant and positive relationship between inflation and stock prices as the Fisher (1930) hypothesis postulates. This also implies that investors in making good portfolio decisions should perhaps view equities as long-term holdings against inflation's erosion of purchasing power.

The question is to what extent and in what ways do output growth, interest rate and inflation rate impact the movement of stock prices, subsequently stock market returns in a developing country like Nigeria? Thus, the objective of this paper is to examine the impact of output growth, interest rate and inflation rate on stock market returns in Nigeria both in the short run and the long run. The rest of the paper is organized as follows; section 2 explains the model, data and methodological framework, section 3 presents the results and interpretations; and section 4 deals with conclusions and policy implications.

\section{Data and Methods}

The empirical analysis was conducted using time series model. The study uses long and up-to date annual time-series data (1986-2012), with a total of 28 observations for each variable. The data for the study, real GDP, NSE-All Share Index, Inflation Rate and Interest Rate, are obtained from Central Bank of Nigeria Statistical Bulletin and Annual Report and Statements of Account for different years. We use minimum rediscount money rate as proxy for interest rate variable and NSE All Share index as proxy for stock market prices. The variables are in log form. We therefore estimate Equation (1) using the ordinary least square (OLS) method. The software application utilized was E-views 7.0.

\section{Model Specification}

The research made use of the following models specified below.

$\mathrm{NSEIt}=\psi 1+\psi 2 \mathrm{INTt}+\psi 3 \mathrm{INFt}+\psi 4 \mathrm{RGDPt}+\varepsilon \mathrm{t}$ 
Where:

NSEI = Nigeria Stock Exchange (NSE) All share Index

INT $=$ Interest Rate

$\mathrm{INF}=$ Inflation Rate

RGDP $=$ Real Gross Domestic Product

\section{Method of Analysis}

This study applied co-integration and error correction modeling to the data obtained. We indeed ascertained the link between stock market prices and macroeconomic growth indices such as real GDP, inflation and interest rates. Cointegration tests are conducted to see if there is a long-run or equilibrium relationship between the variables. Two popular cointegration tests, namely, the Engel-Granger (EG) test and the Johansen test are used. The EG test is contained in Engel and Granger (1987), while the Johansen test is found in Johansen (1988) and Johansen and Juselius (1990). The EG test involves testing for stationarity of the residuals. If the residuals are stationary at level, it implies that the variables under consideration are cointegrated. The EG approach could exhibit some degree of bias arising from the stationarity test of the residuals from the chosen equation. The EG test assumes one cointegrating vector in systems with more than two variables and it assumes arbitrary normalization of the cointegrating vector. Besides, the EG test is not very powerful and robust when compared with the Johansen cointegration test. Thus, in this study we apply Johansen test.

\section{Results and Interpretation}

\section{Unit Root Test}

Appropriate test has been developed by Dickey and Fuller (1979) to test whether a time series has a unit root. Tables 1 therefore provide the results of the unit root tests. Table 1 shows the Dickey and Fuller (ADF) test with constant only. The hypothesis of unit root against the stationary alternative is not rejected for all the variables at level except inflation rate. However, the first differences of NSE- all share index and interest rate are stationary and second difference for real GDP. Hence, we conclude that these variables are integrated of order 2.

Table 1. Results of (ADF) Unit Root Test

\begin{tabular}{|l|l|l|l|l|}
\hline Variables & constant only & Critical values & Decision \\
\hline NSEASI & Level & -0.652684 & $-3.808546^{* * *}$ & $\mathrm{I}(1)$ \\
& 1st difference & $-2.827554 *$ & $-3.020686^{* *}$ & \\
\hline RGDP & Level & 1.800920 & $-3.737853^{* * *}$ & $\mathrm{I}(2)$ \\
& 1st difference & -1.753185 & $-2.991878^{* *}$ & \\
& 2nd difference & $-6.617123 * * *$ & $-2.635542^{*}$ & \\
\hline INFL & Level & $-2.726992 *$ & $-3.737852^{* * *}$ & $\mathrm{I}(0)$ \\
& 1st difference & -2.258831 & $-2.991878 * *$ & \\
\hline INTRATE & Level & -2.538489 & $-3.769597 * * *$ & $\mathrm{I}(1)$ \\
& 1st difference & $-3.325935^{* *}$ & $-3.004861 * *$ & \\
\hline
\end{tabular}

ADF Critical values at: $1 \%(* * *), 5 \%(* *)$ and $10 \%(*)$ 
Following from the results presented in tables 1 that the variables are integrated, it therefore necessary to determine whether there is at least one linear combination of the variables that is 1(0). The Co-integration test performed for the long run relationship among series by using Johansen and Juselius co-integration test is presented in Table 2. The result show a co-integration rank of one in both trace test and max-eigen value test at $5 \%$ significance level.

Table 2. Cointegration Rank Test Assuming Linear Deterministic Trend

\begin{tabular}{|l|l|l|l|l|}
\hline $\begin{array}{l}\text { Null } \\
\text { Hypothesis }\end{array}$ & $\begin{array}{l}\text { Alternative } \\
\text { Hypothesis }\end{array}$ & $\begin{array}{l}\text { Test } \\
\text { Statistics }\end{array}$ & $\begin{array}{l}0.05 \text { Critical } \\
\text { Value }\end{array}$ & $\begin{array}{l}\text { Probability } \\
\text { Value }\end{array}$ \\
\hline $\mathrm{r}=0$ & $\mathrm{Trace}$ Statistics & & \\
\hline $\mathrm{r}=1$ & $\mathrm{r}=2$ & $55.29702^{*}$ & 47.85613 & 0.0086 \\
\hline & & 23.10222 & 29.79707 & 0.2411 \\
\hline $\mathrm{r}=0$ & $\mathrm{Max}>0$ & 32.19480 & & \\
\hline $\mathrm{r} \leq 1$ & $\mathrm{r}>1$ & 11.11932 & 27.58434 & 0.0119 \\
\hline
\end{tabular}

aDenotes rejection of the null hypothesis at 0.05 level

In other words, a long-run stable relationship among the variable exists. This implies that all share index, inflation, interest rate and real GDP move together in the long run.

Since the existence of a long-run relationship has been established, the short-run dynamics of the model can be established within an error correction model. In order to estimate the impact of the macroeconomic growth indices such as real GDP, inflation and interest rates on stock market prices, we will use a simple formulation of an error correction model. We specify the error correction term as follows;

$\mathrm{NSEIt}=\psi 1+\psi 2 \mathrm{INTt}+\psi 3 \mathrm{INFt}+\psi 4 \mathrm{RGDPt}+\varepsilon \mathrm{t} \quad$ (from equation 1$)$

$\varepsilon \mathrm{t}=\mathrm{NSEIt}-\psi 1-\psi 2 \mathrm{INTt}-\psi 3 \mathrm{INFt}-\psi 4 \mathrm{RGDPt}$

where $\varepsilon t$ is the residual term and $\psi i$ is a co-integrating coefficients. From equation (1), we can formulate a simple ECM as:

$\Delta \mathrm{NSEIt}=\omega 0+\omega 1 \Delta \mathrm{INTt}+\omega 2 \Delta \mathrm{INFt}+\omega 3 \Delta \mathrm{RGDPt}+\lambda \varepsilon \mathrm{t}-1+\nu \mathrm{t} \quad(10)$

عt-1 = NSEIt-1 - $\psi 1$ - $\psi 2$ INTt-1 - $\psi 3$ INFt-1 - $\psi 4$ RGDPt-1

Specifically from the ECM expressed in equation (11), wi capture any immediate, short term or contemporaneous effect that RGDP, INF, and INT have on NSEI. The coefficient $\psi$ reflects the long-run equilibrium effect of RGDP, INF, and INT on NSEI and the absolute value of $\lambda$ decides how quickly the equilibrium is restored.

Table 4. OLS Result (with NSEIt as dependent variable)

\begin{tabular}{|l|l|l|}
\hline Variable & Coefficient & Probability \\
\hline C & -32.76478 & 0.0032 \\
\hline RGDP & 3.496803 & 0.0000 \\
\hline INF & 0.331618 & 0.1476 \\
\hline INT & -1.832824 & 0.0009 \\
\hline R2 $=0.853542$ & F-statistic $=42.73801$ \\
Prob(F-statistic) $=0.0000$ & Durbin-Watson stat $=0.528731$ \\
\hline
\end{tabular}


Table 4 result shows that one percentage point rise in real GDP and inflation rate will cause stock markets prices to increase by about 3.5 percent and 0.34 percent respectively. More so, one percent increase in interest rate will bring about a fall of about 2 percent in stock markets prices. This result, as expected, shows that interest rate has a significant and negative effect on NSE-All share index returns. This indicates that interest rate represents alternative investment opportunities. As the interest rate rises, investors tend to invest less in stocks, causing stock prices to fall.

Whereas, the result of error correction model is presented in Table 5

Table 5. OLS Result (with $\triangle$ NSEI as dependent variable)

\begin{tabular}{|l|l|l|}
\hline Variable & Coefficient & Probability \\
\hline $\mathrm{C}$ & 0.203599 & 0.0961 \\
\hline$\Delta \mathrm{RGDP}$ & 0.102812 & 0.9523 \\
\hline$\Delta \mathrm{INF}$ & 0.007689 & 0.9432 \\
\hline$\Delta \mathrm{INT}$ & -0.316564 & 0.3257 \\
\hline Ecm $(-1)$ & -0.107877 & 0.3530 \\
\hline
\end{tabular}

$\Delta \quad$ = first difference operator

The P-value of the error correction term coefficient in Table 5, shows that it is not statistically significant at a $10 \%$ level but it has correct sign i.e negative sign. We can therefore infer that only about 11 percent of the disequilibrium between long term and short term variables is corrected within the year. If the NSE- All share index is one percentage point above the equilibrium real GDP, inflation rate and interest rate, then the NSE- All share index will start falling by about 0.107877 percentage points on average in the next year.

Table 8. Pair-wise Granger Causality Test

\begin{tabular}{|c|c|c|c|}
\hline Null Hypothesis & Lag & Prob. & Decision \\
\hline INF does not Granger Cause NSEI & 5 & 0.8044 & \multirow{2}{*}{$\begin{array}{l}\text { Uni-directional } \\
\text { From NSEI to INF }\end{array}$} \\
\hline NSEI does not Granger Cause INF & 5 & 0.0234 & \\
\hline INT does not Granger Cause NSEI & 5 & 0.6059 & \multirow[t]{2}{*}{ No Causality } \\
\hline NSEI does not Granger Cause INT & 5 & 0.5537 & \\
\hline RGDP does not Granger Cause NSEI & 5 & 0.9106 & \multirow{2}{*}{$\begin{array}{l}\text { Uni-directional } \\
\text { From NSEI to RGDP }\end{array}$} \\
\hline NSEI does not Granger Cause RGDP & 5 & 0.0097 & \\
\hline INT does not Granger Cause INF & 5 & 0.0135 & \multirow{2}{*}{$\begin{array}{l}\text { Uni-directional } \\
\text { From INT to INF }\end{array}$} \\
\hline INF does not Granger Cause INT & 5 & 0.4366 & \\
\hline RGDP does not Granger Cause INF & 5 & 0.1027 & \multirow[t]{2}{*}{ No Causality } \\
\hline INF does not Granger Cause RGDP & 5 & 0.1961 & \\
\hline RGDP does not Granger Cause INT & 5 & 0.4904 & \multirow[t]{2}{*}{ No Causality } \\
\hline INT does not Granger Cause RGDP & 5 & 0.2609 & \\
\hline
\end{tabular}

With 5 lags at $5 \%$ level of significance, the test suggests that there is a unidirectional causality that runs from NSEI to INF, NSEI to RGDP and INT to INF. Others show evidence of no causality between the variable. We infer from the causality test that NSE-All Share Index that is used to capture the stock market price has a feed-back effect on the rate of inflation and real gross domestic product. More so, causality that runs from interest rate to inflation provides support for fisher effect in Nigeria, which is consistent with the finding of Alimi \& Ofonyelu (2013) and Omotor (n.a.) 


\section{Conclusions and Policy Implications}

This paper employed OLS, cointegration test and granger causality to examine the impact of output growth, interest rate and inflation rate on stock market returns both in the short run and in the long run using time series data for Nigeria for the period from 1986 to 2012. Our findings suggest that NSE-All share index, inflation rate, interest rate and real GDP move together in the long run. Also, we found that interest rate and output growth have significant role on stock market return and performance. This indicates that interest rate represents alternative investment opportunities such that high interest rate might serve as a motivation for investor to invest in money market instead of capital market. As the interest rate rises, investors tend to invest less in stocks, causing stock prices to fall. Finally, we infer from the causality test that NSE-All Share Index has a feed-back effect on the rate of inflation and real gross domestic product and found a support for fisher effect in Nigeria. Policy implication is that policy maker should endeavor to keep interest rate low and stable so that investors can raise the required investment fund from the capital market.

\section{References}

Alimi. R. S, \& Ofonyelu, C. C. (2013). Toda-yamamoto causality test between money Market interest rate and expected inflation: The fisher hypothesis revisited. European Scientific Journal, 9(7), 125-142

Asaolu, T. O., \& Ogunmuyiwa, M. S. (2011). An Econometric Analysis of the Impact of Macroeconomic Variables on Stock Market Movement in Nigeria. Asian Journal of Business Management, 3(1), 72-78

Cheung, Y., \& Lai, K. (1993). Finite-sample sizes of Johansen's likelihood ratio tests for cointegration. Oxford bulletin of Economics and Statistics, 55, 313-328. http://dx.doi.org/10.1111/j.1468-0084.1993.mp55003003.x

Dickey, D., \& Fuller, W. (1979). Distribution Of The Estimators For Autoregressive Time Series With A Unit Root. Journal of the American Statistical Association, 74, 427-731.

Fisher, I., (1930). The theory of interest. New York: Macmillan.

Greene, W. H., (2000). Econometric Analysis (4e). New Jersey: Prentice-Hall, Inc.

Harris, R. (1995). Using cointegration analysis in econometric modelling. London: Prentice Hall.

Johansen, S., \& K. Juselius, (1990). Maximum likelihood estimation and inference on cointegration-with applications to the demand for money. Oxford Bulletin of Economics and Statistics, 52(2), 169-210. http://dx.doi.org/10.1111/j.1468-0084.1990.mp52002003.x

Johansen, S., (1991). Estimation and hypothesis testing of cointegration vectors in Gaussian vector autoregressive models. Econometrica. 59, 1551-1580. http://dx.doi.org/10.2307/2938278

Johansen, S., (1995). Likelihood-Based Inference in Cointegrated Vector Autoregressive 


\section{Macrothink}

Business and Economic Research ISSN 2162-4860 2014, Vol. 4, No. 2

Models. Oxford: Oxford University Press. http://dx.doi.org/10.1093/0198774508.001.0001

Kolari, J. (2001). Stock Prices and Inflation. Journal of Financial Research, 4(24), 587-602

Maysami, C. Ramin \& Koh, S. Tiong, (2000). AVector Error Correction Model of the Singapore Stock Market, International Review of Economics and Finance, 9(1), 79-96. http://dx.doi.org/10.1016/S1059-0560(99)00042-8

Muradoglu, G., Taskin F, \& Bigan, I. (2000). Causality between stock returns and macroeconomic variables in emerging markets. Russian East Eur. Finance Trade, 36(6), 33-53.

Omotor, D. G. (n.a). Relationship between Inflation and Stock Market Returns: Evidence from Nigeria. Journal of Applied Statistics, 1(1), 1-15

Osterwald-Lenum, M. (1992). A note with quintiles of the asymptotic distribution of the maximum likelihood cointegration rank test statistics. Oxford bulletin of Economics and Statistics, 54, 461-472. http://dx.doi.org/10.1111/j.1468-0084.1992.tb00013.x

Udegbunam, R. I., \& P. O. Eriki. (2001). Inflation and Stock Price Behavior: Evidence from Nigerian Stock Market. Journal of Financial Management \& Analysis, XX (14).

Victor, O., \& Kuwornu , J. K. M. (2011). Analyzing the effect of macroeconomic variables on stock market returns: Evidence from Ghana. Journal of Economics and International Finance $3(11), 605-615$.

Wongbampo, P., \& Sharma, S. C. (2002). Stock market and macroeconomic fundamental dynamic interactions: ASEAN-5 countries. J. Asian Econ., 13, 27-51. http://dx.doi.org/10.1016/S1049-0078(01)00111-7

\section{Copyright Disclaimer}

Copyright for this article is retained by the author(s), with first publication rights granted to the journal.

This is an open-access article distributed under the terms and conditions of the Creative Commons Attribution license (http://creativecommons.org/licenses/by/3.0/). 